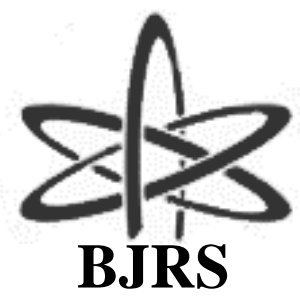

\author{
BRAZILIAN JOURNAL \\ $\mathrm{OF}$ \\ RADIATION SCIENCES \\ 07-2A (2019) 01-19
}

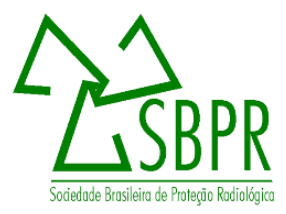

\title{
Radon exhalation from granitic rocks
}

\author{
Del Claro ${ }^{a}$ F., Paschuk ${ }^{a}$ S.A., Corrêa ${ }^{a}$ J.N., Mazer ${ }^{a}$ W., Narloch ${ }^{a}$ D.C., Martin ${ }^{a}$ A.C., \\ Denyak ${ }^{\mathrm{b}} \mathrm{V}$. \\ ${ }^{a}$ Federal University of Technological - Paraná /CPGEI, 80230-901, Curitiba, Paraná, Brazil \\ flaviadelclaro@gmail.com \\ ${ }^{b}$ Pelé Little Prince Research Institute /Medicine, 80250-060, Curitiba, Paraná, Brazil
}

\begin{abstract}
Naturally occurring radionuclides such as radon $\left({ }^{222} \mathrm{Rn}\right)$, its decay products and other elements from the radioactive series of uranium $\left({ }^{238} \mathrm{U}\right.$ and $\left.{ }^{235} \mathrm{U}\right)$ and thorium $\left.{ }^{232} \mathrm{Th}\right)$ are an important source of human exposure to natural radioactivity. The worldwide evaluation of health radiobiological effects and risks from population exposure to natural radionuclides is a growing concern. According to EPA, almost $50 \%$ of average annual dose of $6.2 \mathrm{mSv}$ is related to natural radionuclides such as radon $\left({ }^{222} \mathrm{Rn}\right)$, thoron $\left({ }^{220} \mathrm{Rn}\right)$, radium $\left({ }^{226} \mathrm{Ra}\right)$, thorium $\left({ }^{232} \mathrm{Th}\right)$ and potassium $\left({ }^{40} \mathrm{~K}\right)$, which are present in modern materials commonly used in construction of dwellings and buildings. The radioactivity of marbles and granites is of big concern since under certain conditions the radioactivity levels of these materials can be hazardous to the population and require the implementation of mitigation procedures. Present survey of the ${ }^{222} \mathrm{Rn}$ and ${ }^{220} \mathrm{Rn}$ activity concentration liberated in the air was performed using commercialized Brazilian granite rocks at national and international market. The ${ }^{222} \mathrm{Rn}$ and ${ }^{220} \mathrm{Rn}$ measurements were performed using the AlphaGUARD instant monitor and RAD7 detector, respectively. This study was performed at the Applied Nuclear Physics Laboratory of the Federal University of Technology Paraná (UTFPR). Obtained results of radon concentration activity in air exhaled studied samples of granites varied from $3 \pm 1 \mathrm{~Bq} / \mathrm{m}^{3}$ to $2087 \pm 19 \mathrm{~Bq} / \mathrm{m}^{3}$, which shows that some samples of granitic rocks represent rather elevated health risk the populatio
\end{abstract}

Keywords: natural radioactivity, granite, radon.

ISSN: 2319-0612

Aceppted: 2018-10-27 


\section{INTRODUCTION}

The human being is constantly exposed to several sources of natural ionizing radiation. Over the years, numerous studies [1 - 4] have been carried out with the objective to evaluate the radiobiological effects and health risks arising from the exposure of the world population to various sources of ionizing radiation.

Radioactive elements such as radon-222 $\left({ }^{222} \mathrm{Rn}\right)$, thoron-220 $\left({ }^{220} \mathrm{Rn}\right)$, radium-226 $\left({ }^{226} \mathrm{Ra}\right)$, thorium-232 $\left({ }^{232} \mathrm{Th}\right)$ and potassium-40 $\left({ }^{40} \mathrm{~K}\right)$ could be found in big variety materials commonly used in construction of dwellings and buildings [1 - 4]. Some of these materials, such as marbles and granites, under certain conditions of temperature, humidity, ventilation and atmospheric pressure could contribute significantly to the indoor activity concentration of radon. In such situation, preventive and corrective radioprotection measures should be implemented for the use of these materials [5].

Many countries as China and Spain show concern and conduct systematic research of radioactivity levels of different types of marketed granites [6, 7]. In addition, countries of the European continent, such as Serbia, have established import, export and transit regulations aimed at controlling the radioactivity of products such as marble and granite [8]. In 2008 the United States of America (USA) reported problems with radioactivity levels and exhalation rate of radon from granite rocks used in countertops. This news disturbed many Brazilian marble and granite manufactures because Brazil is one of the largest exporters of rock to the USA [9]. In Brazil, there were conducted few studies aimed at evaluating the radioactivity of granitic rocks marketed internally in the country and exported, as well as the levels of radioactivity and doses received by the population and workers from marble and granite factories [10, 11].

It has to be mentioned that Brazil has no specific legislation that establishes the limits or reference levels for radon activity in dwellings. However, the regulatory position on the CNENNN-3.01 standard provides individual annual dose limits, and effective dose limit values the sources of external exposure are considered [12]. On the other hand, the Jorge Duprat Figueiredo Foundation for Safety and Occupational Medicine (FUNDACENTRO), in its document entitled "Marble factories - Reference Manual - Safety and Health at Work Recommendations"[13], 
provides technical recommendations and control measures aimed to minimize the exposure of marble workplace workers to chemical agents, noise, ergonomic and environmental hazards. However, the manual does not contemplate measures to evaluate and control those workers exposure to natural radioactivity from granitic rocks.

The implementation of mitigation measures is necessary for the export of granites. Thus, these materials can be exported to other countries in order to comply with international safety legislation that establishes acceptable levels of radioactivity for the entry, movement and marketing of foreign products. Within this context, the present work was performed with the objective to evaluate the human exposure to radioactivity of radon from Brazilian granite rocks commercialized by marble and granite factories and to propose a control protocol that aims to reduce the exposure to radiation from these materials.

\section{MATERIALS AND METHODS}

\subsection{Sample collections}

Present research was conducted using 24 samples of granitic rocks, which were submitted to the measurements of ${ }^{222} \mathrm{Rn}$. The samples of granites were provided by a marble factory located in Curitiba, the capital of Paraná state. Commercial names of studied granites and the number of samples of the same type (color and composition) are presented in Table 1.

Table 1: Types of granitic rocks evaluated in present work.

\begin{tabular}{cc}
\hline Granitic rocks (commercial name) & Number of samples \\
\hline Marrom Guaíba & 4 \\
Verde Boreal Escuro & 2 \\
Sea Foam Green & 3 \\
Verde Cristal & 1 \\
Verde Filus & 3
\end{tabular}




$\begin{array}{cc}\text { Boreal Branco } & 1 \\ \text { Preto Itapoa } & 2 \\ \text { Boreal Goudi } & 1 \\ \text { Itaipu } & 4 \\ \text { Rosa Curitiba } & 1 \\ \text { Prata Mar } & 2\end{array}$

\subsection{Treatment of samples}

The Figure 1-a shows a crude granite block and the place of sample extraction for the purpose of present research. The surface area of each granite sample was calculated using MATLAB ${ }^{\circ}$ software.

For the calculation of the surface area, all the plane faces of the granitic sample were photographed with known resolution (dpi). These images were loaded into MATLAB® software which, by means of a developed code, calculated the total surface area of each sample in $\mathrm{m}^{2}$.

Already, the granite volume was obtained by using displacement method of the water level by immersing the granite sample in glass beaker graduated in milliliters. Thus, the displacement of the water column in milliliters represents the volume of the granite rock immersed in the glass beaker. Table 2 shows the volume and surface area of studied 24 granitic rock samples.

Figure 1: (a) Block of granitic rock and place of extraction of a sample, (b) Samples of granites sealed in glass vessel. 


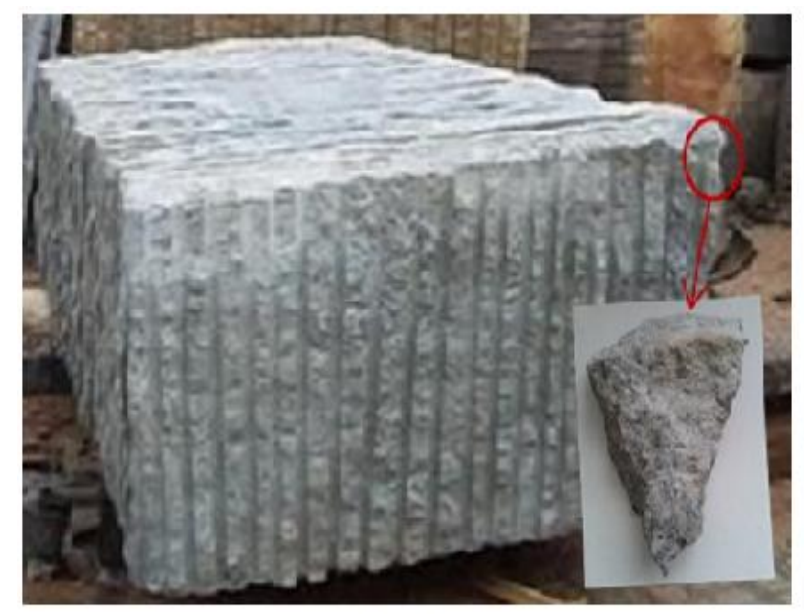

(a)

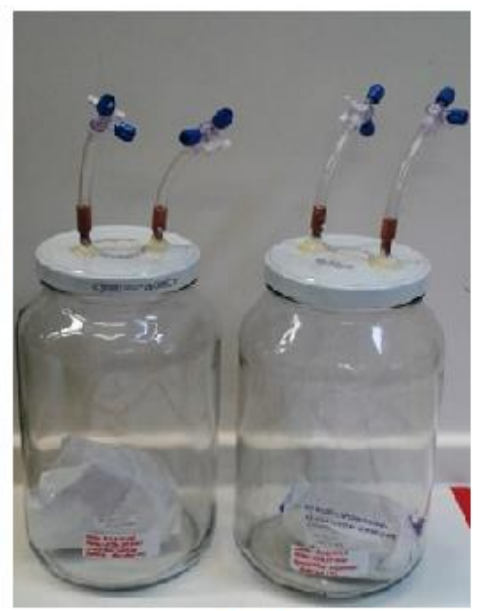

(b)

Source: own authorship

Table 2: Volume and surface area of granite samples.

\begin{tabular}{ccc}
\hline Granite samples & Volume, $\left[\mathbf{m}^{3}\right]$ & Surface area, $\left[\mathbf{m}^{2}\right]$ \\
\hline Marrom Guaíba (A) & 0.00012 & 0.014 \\
Marrom Guaíba (B) & 0.00012 & 0.015 \\
Marrom Guaíba (C) & 0.00013 & 0.011 \\
Marrom Guaíba (D) & 0.00004 & 0.017 \\
Verde Boreal Escuro (A) & 0.00009 & 0.010 \\
Verde Boreal Escuro (B) & 0.00027 & 0.019 \\
Sea Foam Green (A) & 0.00016 & 0.014 \\
Sea Foam Green (B) & 0.00015 & 0.018 \\
Sea Foam Green (C) & 0.00020 & 0.020 \\
Verde Cristal & 0.00017 & 0.021 \\
Verde Filus (A) & 0.00014 & 0.017 \\
Verde Filus (B) & 0.00009 & 0.012 \\
Verde Filus (C) & 0.00011 & 0.016 \\
Boreal Branco & 0.00015 & 0.015 \\
Preto Itapoa (A) & 0.00009 & 0.008 \\
\hline
\end{tabular}




$\begin{array}{cll}\text { Preto Itapoa (B) } & 0.00012 & 0.013 \\ \text { Boreal Goudi } & 0.00009 & 0.015 \\ \text { Itaipu (A) } & 0.00011 & 0.013 \\ \text { Itaipu (B) } & 0.00018 & 0.020 \\ \text { Itaipu (C) } & 0.00007 & 0.015 \\ \text { Itaipu (D) } & 0.00007 & 0.019 \\ \text { Rosa Curitiba } & 0.00010 & 0.015 \\ \text { Prata Mar (A) } & 0.00014 & 0.012 \\ \text { Prata Mar (B) } & 0.00012 & 0.018\end{array}$

\subsection{Determination of ${ }^{222} \mathrm{Rn}$}

The measurements of ${ }^{222} \mathrm{Rn}$ and ${ }^{220} \mathrm{Rn}$ activity concentrations in air related to the granitic rocks were performed using the AlphaGUARD instant monitor (Saphymo GmbH) and RAD7 detector (Durridge Company). The measurements were performed at the Applied Nuclear Physics Laboratory of the Federal University of Technology - Paraná (UTFPR). The calibration of the detectors were performed in collaboration with the Natural Radioactivity Laboratory of the Center of Nuclear Technology Development Center (CDTN) and the National Institute of Radiological Sciences (NIRS) in Japan.

For the measurements of ${ }^{222} \mathrm{Rn}$ and ${ }^{220} \mathrm{Rn}$ activity concentrations, the samples of granitic rocks were individually sealed in glass vessels for 40 days (ten half-lives of radon, approximately) in order to achieve secular equilibrium between radon-222 $\left({ }^{222} \mathrm{Rn}\right)$ and radium-226 $\left({ }^{226} \mathrm{Ra}\right)$ (Figure 1b). Evidently, during this time thoron $\left({ }^{220} \mathrm{Rn}\right)$ reaches the secular equilibrium with radium-224 $\left({ }^{224} \mathrm{Ra}\right)\left(\mathrm{T}_{1 / 2}=3.6\right.$ days $)$ and thorium-228 $\left({ }^{228} \mathrm{Th}\right)\left(\mathrm{T}_{1 / 2}=1.9\right.$ years $)$.

The measurements of ${ }^{222} \mathrm{Rn}$ activity concentration in air were performed during 24 hours using 10min/flow mode by means of close circuit, which included sealed glass vessel with rock sample inside, Tygon hoses, Alpha PUMP, air filters, AlphaGUARD detector and rotameter. The Figure 2 shows a schematic drawing of the closed circuit used for sample and background measurements. 
Figure 2: Schematic drawing of the closed circuit of measurements performed with the AlphaGUARD.

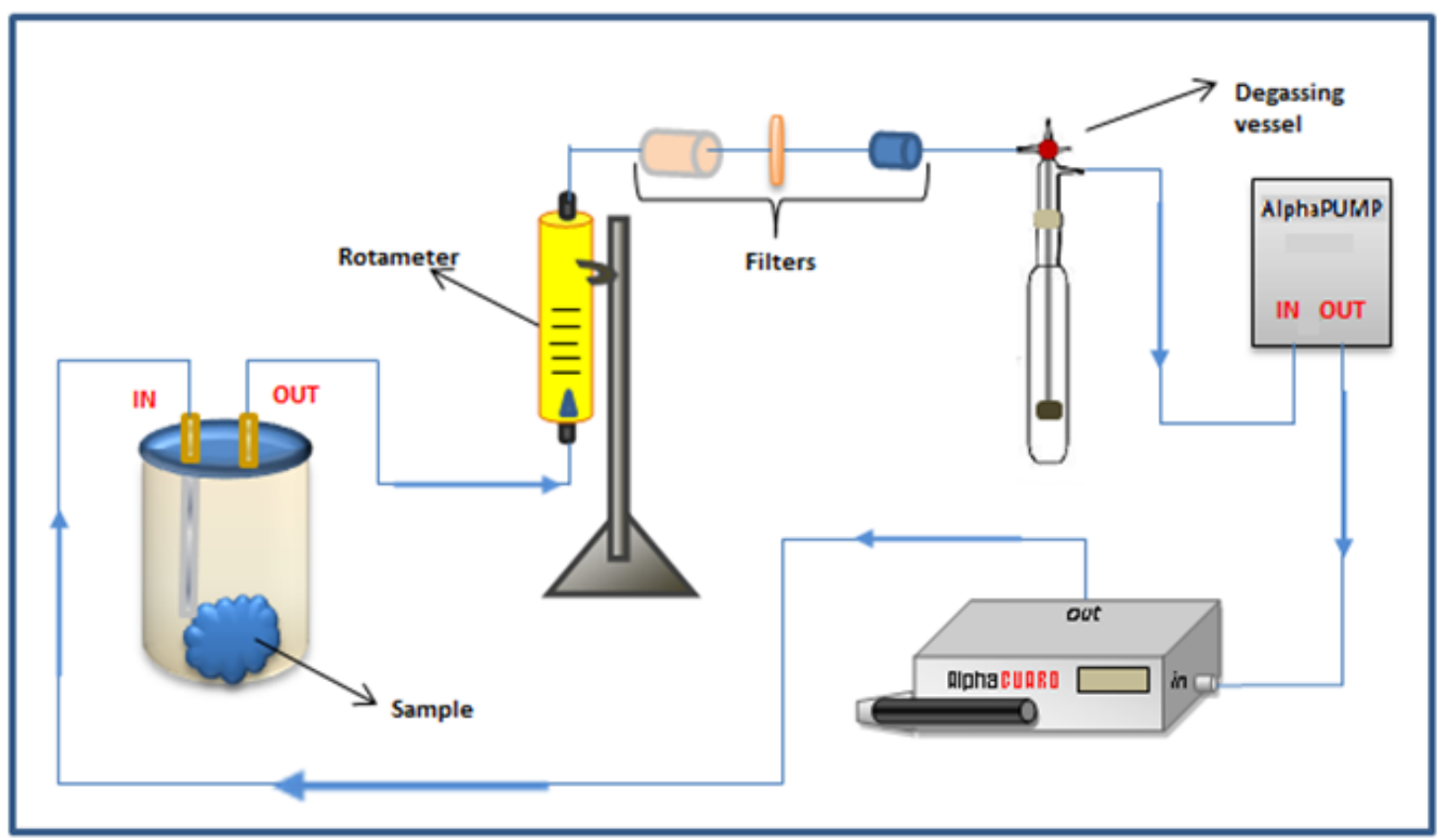

Source: own authorship

A glass vessel closed without sample of granitic rock inside was separated to perform the background measurements. Before the measurement of the ${ }^{222} \mathrm{Rn}$ concentration of each sample, a measurement of the background glass vessel was done. However, only the first measurement of the background was adopted as the background reference level of the equipment, and this background measure was discounted from the values of ${ }^{222} \mathrm{Rn}$ concentrations activity obtained in the granitic rocks samples analyzes.

The background measurements that interpolated the measurements of the radon concentrations of the samples were carried out with the objective of verifying that the background value of the AlphaGUARD equipment had undergone alteration due to the possible detachment of particles from the samples and accumulation there of inside the ionization chamber of the equipment.

For the background and ${ }^{222} \mathrm{Rn}$ activity concentrations measurements, the AlphaPUMP was adjusted to run with a flow rate of $0.5 \mathrm{~L} / \mathrm{min}$ and the AlphaGUARD was operated in 10min/flow mode. The background measurements were conducted for 1 hour. 
The AlphaGUARD equipment has a measure range from 2 to 2,000,000 $\mathrm{Bq} / \mathrm{m}^{3}$, with a calibration error of 3\% [14] and the RAD7 detector operates in radon concentration range of 4 $750.000 \mathrm{~Bq} / \mathrm{m}^{3}$ [15].

Obtained experimental data of the ${ }^{222} \mathrm{Rn}$ activity measurements performed with AlphaGUARD monitor were analyzed using the DataEXPERT software supplied by the manufactures of the equipment [14]. The final ${ }^{222} \mathrm{Rn}$ activity concentration from the granites was obtained by subtracting the background value from the ${ }^{222} \mathrm{Rn}$ gas concentration measured by the AlphaGUARD.

The samples that presented radon activity concentration above $100 \mathrm{~Bq} / \mathrm{m}^{3}$ in measurements using AlphaGUARD instant monitor, were submitted to the measurements with RAD7 detector. Thus, from 24 samples of granitic rocks, 14 samples were evaluated with RAD7 detector.

The measurements of thoron were performed with the RAD7 detector using closed circuit, which included sealed glass vessel with rock sample inside, Tygon hoses, DRYSTIK as gas pump [15], charcoal air filter, $25 \mathrm{lb}$ desiccant with Drierite and three way valves. The Figure 3 shows a schematic drawing of the closed circuit used for sample and background measurements. Recommended protocol WAT250 was used for thoron measurements.

The background was evaluated using four cycles of 5 minutes and the measurements of radon activity associated with granite samples were made in 99 cycles of 10 minutes each using the WAT250 protocol pre-programed by the detector manufactures.

Figure 3: Schematic drawing of the close circuit for radon activity measurements using RAD7 detector. 


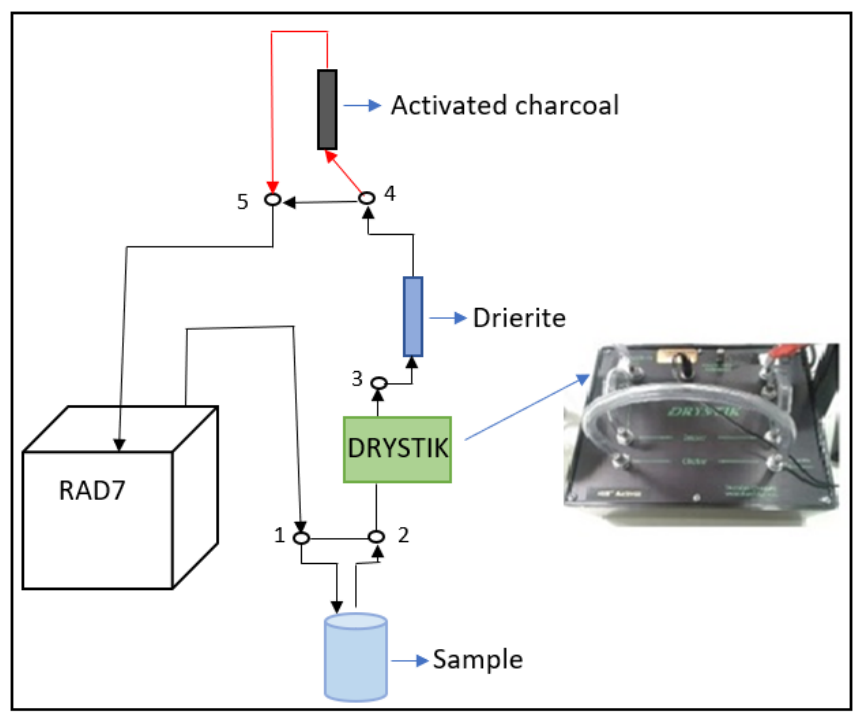

Source: own authorship

The ${ }^{222} \mathrm{Rn}$ diffusive entry rate from the granitic rocks was calculated using the Equation 1 [16]. In this equation $\mathrm{F}$ corresponds to the ${ }^{222} \mathrm{Rn}$ exhalation rate of the granites, $\mathrm{CRn}$ represents the radon activity concentration measured with AlphaGUARD monitor in $\left[\mathrm{Bq} / \mathrm{m}^{3}\right]$, VAR is the volume of the entire measurements circuit in [L], $S$ is the surface area of sample in $\left[\mathrm{m}^{2}\right]$ and $\lambda$ is the radon decay constant. Obtained results are presented in Table 4.

$$
\mathrm{F}=3.6 \times 10^{3} \frac{\mathrm{C}_{\mathrm{Rn} \times \mathrm{V}_{\text {ar }}}}{\mathrm{S}} \lambda,\left[\mathrm{Bq} /\left(\mathrm{m}^{2} \mathrm{~h}\right)\right]
$$

At the next step, those calculated results of the diffusive entry rate were extrapolated to a model of reference masonry building with standard dimensions of internal volume of $(5 \mathrm{x} 4 \times 2.8) \mathrm{m}^{3}$ and with an air exchange rate of $1 \mathrm{~h}^{-1}$ established by the UNSCEAR Report [17]. Thus, the rate of radon entry FC from the building materials in such reference building, which are using granite construction elements, was obtained by Equation 2.

$$
F_{c}=F \frac{A}{V},\left[B q /\left(m^{3} h\right)\right]
$$


where $\mathrm{F}$ is the radon diffusive entry rate (see the Equation 1), $\mathrm{A}$ is the surface areas of the walls, floor slab and ceiling in $\left[\mathrm{m}^{2}\right]$ and $\mathrm{V}$ is the internal volume of reference house in $\left[\mathrm{m}^{3}\right]$.

\section{RESULTS AND DISCUSSION}

The activity concentration values of ${ }^{222} \mathrm{Rn}$ and associated errors for all studied samples of granite rock are listed in Table 3.

Table 3: Concentrations of ${ }^{222} \mathrm{Rn}$ in the granite samples measured with the AlphaGUARD.

\begin{tabular}{cc}
\hline Granite samples & $\begin{array}{r}\text { 222 Rn activity concentration } \\
\text { and error, }\left[\mathbf{B q} / \mathbf{m}^{3}\right]\end{array}$ \\
\hline Marrom Guaíba (A) & $1382 \pm 15$ \\
Marrom Guaíba (B) & $1961 \pm 19$ \\
Marrom Guaíba (C) & $2087 \pm 19$ \\
Marrom Guaíba (D) & $2050 \pm 19$ \\
Verde Boreal Escuro (A) & $21 \pm 1$ \\
Verde Boreal Escuro (B) & $11 \pm 2$ \\
Sea Foam Green (A) & $182 \pm 4$ \\
Sea Foam Green (B) & $461 \pm 8$ \\
Sea Foam Green (C) & $578 \pm 8$ \\
Verde Cristal & $94 \pm 3$ \\
Verde Filus (A) & $21 \pm 1$ \\
Verde Filus (B) & $15 \pm 1$ \\
Verde Filus (C) & $15 \pm 1$ \\
Boreal Branco & $201 \pm 5$ \\
Preto Itapoa (A) & $3 \pm 1$ \\
Preto Itapoa (B) & $10 \pm 1$ \\
Boreal Goudi & $161 \pm 4$ \\
\hline
\end{tabular}




$\begin{array}{cc}\text { Itaipu (A) } & 732 \pm 10 \\ \text { Itaipu (B) } & 1097 \pm 12 \\ \text { Itaipu (C) } & 135 \pm 4 \\ \text { Itaipu (D) } & 351 \pm 6 \\ \text { Rosa Curitiba } & 260 \pm 5 \\ \text { Prata Mar (A) } & 643 \pm 9 \\ \text { Prata Mar (B) } & 448 \pm 7\end{array}$

One can see that a total of $54 \%$ of the granitic rock samples measured with the AlphaGUARD monitor presented ${ }^{222} \mathrm{Rn}$ activity concentrations higher than $200 \mathrm{~Bq} / \mathrm{m}^{3}$, and $41 \%$ of the 24 evaluated samples are associated with radon activity concentrations higher than $400 \mathrm{~Bq} / \mathrm{m}^{3}$. The samples of Marrom Guaíba granite present the highest ${ }^{222} \mathrm{Rn}$ activity concentrations above $1000 \mathrm{~Bq} / \mathrm{m}^{3}$.

Considering the exhalation of radon for the environment, these results are important when considering the reference levels established by international regulatory agencies such as UNSCEAR [18] and ICRP [19], which established as upper limit for the radon activity concentrations in air 200 $\mathrm{Bq} / \mathrm{m}^{3}$ and $300 \mathrm{~Bq} / \mathrm{m}^{3}$, respectively.

The ${ }^{222} \mathrm{Rn}$ diffusive rate from the granitic rocks was calculated too, and the ${ }^{222} \mathrm{Rn}$ exhalation rate are presented in Table 4.

Table 4: Radon exhalation rate from studied samples of granites.

\begin{tabular}{cc}
\hline Granite samples & $\boldsymbol{F},\left[\mathbf{B q} /\left(\mathbf{m}^{2} \cdot \mathbf{h}\right)\right]$ \\
\hline Marrom Guaíba (A) & 9.551628 \\
Marrom Guaíba (B) & 0.001293 \\
Marrom Guaíba (C) & 0.001946 \\
Marrom Guaíba (D) & 0.001225 \\
Verde Boreal Escuro (A) & 0.000021 \\
Verde Boreal Escuro (B) & 0.000005 \\
Sea Foam Green (A) & 0.000130 \\
Sea Foam Green (B) & 0.000256 \\
\hline
\end{tabular}




\begin{tabular}{cl}
\hline Sea Foam Green (C) & 0.000293 \\
Verde Cristal & 0.000045 \\
Verde Filus (A) & 0.000012 \\
Verde Filus (B) & 0.000012 \\
Verde Filus (C) & 0.000010 \\
Boreal Branco & 0.000136 \\
Preto Itapoa (A) & 0.000004 \\
Preto Itapoa (B) & 0.000008 \\
Boreal Goudi & 0.000111 \\
Itaipu (A) & 0.000560 \\
Itaipu (B) & 0.000538 \\
Itaipu (C) & 0.000092 \\
Itaipu (D) & 0.000191 \\
Rosa Curitiba & 0.000169 \\
Prata Mar (A) & 0.000545 \\
Prata Mar (B) & 0.000254 \\
\hline
\end{tabular}

The Table 5 shows the results of diffusive entry rate were extrapolated to a model of reference masonry building with standard dimensions of internal volume of $(5 \times 4 \times 2.8) \mathrm{m}^{3}$. The rate of radon entry from the building materials in such reference building is denominated of $\mathrm{FC}$, and the calculation considered the use of the granite in all the walls in the construction. Associated uncertainties were calculated using the experimental errors and following the uncertainty propagation rules.

Table 5: Radon entry rate into internal volume of air of reference masonry building.

\begin{tabular}{cc}
\hline Granite samples & $\boldsymbol{F}_{C}$ and error, $\left[\mathbf{B q} /\left(\mathbf{m}^{\mathbf{3} \cdot \mathbf{h}}\right)\right]$ \\
\hline Marrom Guaíba (A) & $15.42 \pm 0.17$ \\
Marrom Guaíba (B) & $21.00 \pm 0.20$ \\
\hline
\end{tabular}




$\begin{array}{cc}\text { Marrom Guaíba (C) } & 31.42 \pm 0.30 \\ \text { Marrom Guaíba (D) } & 19.80 \pm 0.18 \\ \text { Verde Boreal Escuro (A) } & 0.34 \pm 0.02 \\ \text { Verde Boreal Escuro (B) } & 0.10 \pm 0.02 \\ \text { Sea Foam Green (A) } & 2.10 \pm 0.05 \\ \text { Sea Foam Green (B) } & 4.13 \pm 0.07 \\ \text { Sea Foam Green (C) } & 4.74 \pm 0.07 \\ \text { Verde Cristal } & 0.72 \pm 0.02 \\ \text { Verde Filus (A) } & 0.20 \pm 0.01 \\ \text { Verde Filus (B) } & 0.20 \pm 0.01 \\ \text { Verde Filus (C) } & 0.15 \pm 0.01 \\ \text { Boreal Branco } & 2.18 \pm 0.05 \\ \text { Preto Itapoa (A) } & 0.06 \pm 0.02 \\ \text { Preto Itapoa (B) } & 0.13 \pm 0.01 \\ \text { Boreal Goudi } & 1.80 \pm 0.04 \\ \text { Itaipu (A) } & 9.05 \pm 0.12 \\ \text { Itaipu (B) } & 8.70 \pm 0.09 \\ \text { Itaipu (C) } & 1.50 \pm 0.04 \\ \text { Itaipu (D) } & 3.10 \pm 0.05 \\ \text { Rosa Curitiba } & 2.72 \pm 0.05 \\ \text { Prata Mar (A) } & 8.80 \pm 0.12 \\ \text { Prata Mar (B) } & 4.10 \pm 0.06\end{array}$

Evidently, the results of Table 5 concerning the rate of indoor radon entry were obtained considering that all surfaces of the reference masonry building are covered by granite rocks. However, usually in dwellings construction only some part of the environment is covered by granite, such as the floor or a bench, for example. Thus, probably the contribution of the radon entry from granitic rocks into environment will be lower. 
Thus, the results presented in Table 5 shows that depending on the amount of granite distributed in the internal environment the resulting indoor radon activity concentrations may be significant. Therefore, it is important to carry out measures of concentration and the ${ }^{222} \mathrm{Rn}$ exhalation rate of the granitic rocks that are used in dwellings construction.

In the year 2008, for example, the United States of America (USA) reported problems with radioactivity levels and exhalation of radon gas from granite rocks used in building benches [9].

In Brazil, there are still few studies aimed at evaluating the radioactivity of granitic rocks exported and marketed internally in the country, as well as evaluating the levels of radioactivity received by the population $[10,11]$.

The levels of ${ }^{222} \mathrm{Rn}$ and ${ }^{220} \mathrm{Rn}$ activity concentrations obtained with RAD7 detector are shown in Table 6. It could be seen that all studied samples of granites, except for Sea Foam Green (A) and Prata Mar (A) rocks, presented the values of ${ }^{222} \mathrm{Rn}$ activity concentration lower than ${ }^{220} \mathrm{Rn}$ activity concentrations.

Obtained rather elevated values for thoron $\left({ }^{220} \mathrm{Rn}\right)$ activity levels in the air of sampling vessel does not represent any significant risk for the health of workers and general public since it's very short half-life of 54.5 seconds [20] almost guarantee the decay of this radionuclide during the exhalation from the rock and subsequent transport in the air of working place and dwelling. Thus, studied samples of granites can be considered as safe materials for use in building and dwelling construction.

Table 6: ${ }^{222} \mathrm{Rn}$ and ${ }^{220} \mathrm{Rn}$ activity concentrations related to the granite samples measured with the RAD7 detector.

\begin{tabular}{|c|c|c|}
\hline Granite samples & $\begin{array}{c}{ }^{222} \mathrm{Rn} \text { activity } \\
\text { concentration } \\
\text { and error, } \\
{\left[\mathrm{Bq} / \mathrm{m}^{3}\right]}\end{array}$ & $\begin{array}{c}{ }^{220} \mathrm{Rn} \text { activity } \\
\text { concentration, } \\
{\left[\mathrm{Bq} / \mathrm{m}^{3}\right]}\end{array}$ \\
\hline Marrom Guaíba (B) & $38 \pm 11$ & $64 \pm 22$ \\
\hline Marrom Guaíba (C) & $203 \pm 15$ & $1110 \pm 49$ \\
\hline Marrom Guaíba (D) & $43 \pm 12$ & $522 \pm 37$ \\
\hline Sea Foam Green (A) & $94 \pm 12$ & $32 \pm 23$ \\
\hline Sea Foam Green (B) & $57 \pm 12$ & $173 \pm 27$ \\
\hline Verde Cristal & $27 \pm 11$ & $33 \pm 23$ \\
\hline Boreal Branco & $15 \pm 10$ & $84 \pm 23$ \\
\hline Boreal Goudi & $48 \pm 11$ & $79 \pm 23$ \\
\hline
\end{tabular}




\begin{tabular}{lcc} 
Itaipu (A) & $53 \pm 12$ & $253 \pm 30$ \\
Itaipu (C) & $39 \pm 11$ & $36 \pm 22$ \\
Itaipu (D) & $47 \pm 11$ & $58 \pm 25$ \\
Rosa Curitiba & $27 \pm 11$ & $192 \pm 28$ \\
Prata Mar (A) & $1127 \pm 24$ & $514 \pm 38$ \\
Prata Mar (B) & $37 \pm 11$ & $53 \pm 22$ \\
\hline
\end{tabular}

Table 7 presents the comparison of experimental results for radon activity concentration in air for three samples of granitic rocks obtained with the AlphaGUARD monitor and RAD7 detector. One can see that the results of radon activity concentrations are different for both detectors (AlphaGUARD and RAD7), but this divergence could be explained considering the statistical errors and that AlphaGUARD monitor does not distinguish the activities of radon isotopes in the air, which means that the results obtained with AlphaGUARD monitor considering the volume of sampling jar with the sample of granite inside represents the summary activity of ${ }^{222} \mathrm{Rn}$ and ${ }^{220} \mathrm{Rn}$ isotopes. The errors included in Table 7 are the uncertainties associated with experimental values of ${ }^{222} \mathrm{Rn}$ and ${ }^{220} \mathrm{Rn}$ activity concentrations given by AlphaGUARD and RAD7 detectors. Thus, both radon detectors AlphaGUARD and RAD7 presented coherent results in relation to the levels of activity concentration.

Table 7: Radon concentrations of the samples in common evaluated with the AlphaGUARD and RAD7 apparatus.

\begin{tabular}{lcc}
\hline \multirow{2}{*}{ Granite samples } & AlphaGUARD & RAD7 \\
\cline { 2 - 3 } & $\begin{array}{r}{ }^{222} \mathrm{Rn} \text { activity concentration } \\
\text { and error, }\left[\mathrm{Bq} / \mathrm{m}^{3}\right]\end{array}$ & $\begin{array}{c}{ }^{22} \mathrm{Rn} \text { activity concentration } \\
\text { and error, }\left[\mathrm{Bq} / \mathrm{m}^{3}\right]\end{array}$ \\
\hline Boreal Branco & $201 \pm 5$ & $100 \pm 85$ \\
Sea Foam Green (A) & $182 \pm 4$ & $126 \pm 26$ \\
Marrom Guaíba (C) & $2087 \pm 19$ & $1313 \pm 52$ \\
\hline
\end{tabular}

For higher values of radon activity concentration obtained with AlphaGUARD monitor it should be recommended to perform the control measurements with the RAD7 detector to identify the specific activities of ${ }^{222} \mathrm{Rn}$ and ${ }^{220} \mathrm{Rn}$ isotopes separately. Such step could be very important since it qualifies better the hazard impact associated with both isotopes and their progeny considering very significant difference of their half-life. 


\section{CONCLUSIONS}

Obtained results of experimentally measured radon and thoron activity concentration in the air associated with 24 types of commercial brands of granitic rock presented rather high values. $41 \%$ of studied samples of granite presented ${ }^{222} \mathrm{Rn}$ activity bigger than the upper level of radon activity in air suggested by international norms and regulation, which shows the importance and necessity to develop the national legislation and norms, which will establish the limits of radioactivity for commercial use of granitic rocks. Such control is very important considering that exported Brazilian granite has to attend the international standards as well.

Considering that the population exposure to natural radiation sources of radiation is recognized as a public health problem, it is of high significance that the industrial sector of extraction and processing of granitic rocks will be prepared for a new scenario of competitiveness with the arrival of national regulatory norms, aimed at radioprotection of the consumers as well as all the individuals involved in the commercialization process of granitic rocks.

The rate of ${ }^{222} \mathrm{Rn}$ entry into internal volume of air can be reduced by covering the surface area of granitic countertops and decorative plates with impermeable waxes that are normally employed in the granites cleaning and care measures. Thus, it would be interesting to measure the ${ }^{222} \mathrm{Rn}$ exhalation rate from granitic rocks that receive this type of treatment.

Actually, we are planning to perform further measurements of radon exhalation using more wide variety of granitic rocks and their characterization using gamma spectrometry for dosimetric and hazard radioactivity indices calculations, with the purpose of better characterizing the radioactive elements present in the samples of granitic rocks and understand the differences of the concentrations of radon in granites of different compositions and colors.

In the future it is planned to carry out more measurements focused on the verification of thoron activity although it does not represent an immediate problem for people due to it's short half-life.

Present survey shows the importance and necessity to develop the national legislation and norms, which will establish the limits of radioactivity for commercial use of granitic rocks. Such control is very important considering that exported Brazilian granite has to attend the international standards. 


\section{ACKNOWLEDGMENT}

The authors are very thankful to CNPq, CAPES, CNEN and Fundação Araucária (Paraná St.) for financial support of this work as well as to the marble factory for collaboration with present research.

\section{REFERENCES}

[1] CSIGE, I.; SZABÓ, Z.S.; SZABÓ, C.S. "Experimental technique to measure thoron generation rate of building material samples using RAD7 detector”. Radiation Measurements, v. 59, p. 201 204, 2013.

[2] HASSAN, N.M.; HOSODA, M.; IWAOKA, K.; SORIMACHI, A.; JANIK, M.; KRANROD, C.; SAHOO, S.K.; ISHIKAWA, T.; YONEHARA, H.; FUKUSHI, M.; TOKONAMI, S. "Simultaneous Measurement of Radon and Thoron Released from Building Materials Used in Japan”. Nuclear Science and Technology, v. 1, p. 404 - 407, 2011.

[3] FATHIVAND, A.A.; AMIDI, J.; NAJAFI, A. "The Natural Radioactivity in the Bricks Used For the Construction of the Dwelling in Tehran Areas of Iran". Radiation Protection Dosimetry, v. 123, p. $1-3,2006$.

[4] TURHAN, S.; BAYKAN, U.N.; SEN, K. "Measurement of the natural radioactivity in building materials used in Ankara and assessment of external doses". Journal of Radiological Protection, v. 28 , p. $83-91,2008$.

[5] EL-DINE, N.W.; EL-SHERSHABY, A.; AHMED, F.; ABDEL-HALEEM, A.S. "Measurement of radioactivity and radon exhalation rate in different kinds of marbles and granites". Applied Radiation and Isotopes, v. 55, p. $853-860,2001$.

[6] XINWEI, L.; LINGQING, W.; XIAODAN, J. "Radiometric analysis of Chinese commercial granites”. Journal of Radioanalytical and Nuclear Chemistry, v. 267, n. 3, p. 669 - 673, 2006.

[7] GUILLÉN, J.; TEJADO, J.J.; BAEZA, A.; CORBACHO, J.A.; MUÑOZ, J.G. “Assessment of radiological hazard of commercial granites from Extremadura (Spain)". Journal of Environmental Radioactivity, v. 132, p. $81-88,2014$. 
[8] "REPUBLIC OF SERBIA. Rulebook on Radioactivity Control of Goods During the Import, Export and Transit. Official Gazette of the Republic of Serbia, n. 44.”. Available at: http://www.srbatom.gov.rs/srbatom/doc/vazeca_akta/RULEBOOK\%20ON\%20RADIOACTIVITY \%20CONTROL\%20OF\%20GOODS\%20DURING\%20IMPORT,\%20EXPORT\%20AND\%20TRA NSIT.pdf, 2011.

[9] ABIROCHAS - Associação Brasileira da Indústria de Rochas Ornamentais. Radioatividade Natural em Materiais Rochosos. Available at: http://www.ivolution.com.br/news/upload_pdf/6169/Radioatividade1.pdf, 2008.

[10] AQUINO, R.R. “Avaliação da Radioatividade Natural em Mármores e Granitos Comerciais do Estado do Espírito Santo", Tese de Doutorado, Programa de Pós-Graduação em Tecnologia Nuclear, Instituto de Pesquisas Energéticas e Nucleares. São Paulo, 2015.

[11] IRD - Instituto de Radioproteção e Dosimetria. "O uso do índices para a classificação de rochas ornamentais", Available at: http://www.iaea.org/inis/collection/NCLCollectionStore/_Public/45/095/45095667.pdf, 2015.

[12] CNEN - Comissão Nacional de Energia Nuclear. Ministério da Ciência e Tecnologia. NE 3.01 "Diretrizes Básicas de Proteção Radiológica", Rio de Janeiro, Brasil. Available at: http://www.cnen.gov.br, 2014.

[13] FUNDACENTRO - Fundação Jorge Duprat Figueiredo de Segurança e Medicina do Trabalho. MARMORARIAS - MANUAL DE REFERÊNCIA - "Recomendações de Segurança e Saúde no Trabalho", Ministério do Trabalho e Emprego, v.1, 2008.

[14] SAPHYMO. The Reference in Professional Radon Measurement - AlphaGUARD. "Manual do usuário, Saphymo". Available at: http://www.radtech.it/Data/Sites/1/media/documents/products/ag_pm_gb_12_144dpi_ebook.pdf, 2016.

[15] DURRIDGE COMPANY Inc. "RAD7 RADON DETECTOR User Manual”, http://www.durridge.com/documentation/RAD7\%20Manual.pdf (2016).

[16] Khan, A.J.; Tyagi, R.K.; Prasad, R. "Measurement of radon exhalation rates from some building materials", Nucl. Tracks Radiat. Meas., v.20, pp.609-610 (1992).

[17] UNSCEAR - United Nations Scientific Committee on the Effects of Atomic Radiation. Exposure from natural radiation sources, Annex B, Volume I, 2000. 
[18] UNSCEAR - United Nations Scientific Committee on the Effects of Atomic Radiation. Sources and Effects of Ionizing Radiation, annex B, Volume I, 2000.

[19] ICRP - International Commission on Radiological Protection. ICRP 126 - Radiological Protection against Radon Exposure. ICRP Publication 126. Ann. ICRP Volume 43, n. 3, 2014.

[20] NNDC - National Nuclear Data Center. "Chart of Nuclides from Brookhaven National Laboratory", www.nndc.bnl.gov/chart (2016). 